\title{
Performance Analysis of National Agricultural Insurance Scheme (NAIS) and Pradhan Mantri Fasal Bima Yojna (PMFBY)
}

\section{Vikas Kumar}

ICAR- National Institute of Agricultural Economics and Policy Research, Pusa, New Delhi, India

*Corresponding author: vikas.kumar1@icar.gov.in

Received: 09-10-2020

Revised: $20-11-2020$

Accepted: $12-12-2020$

ABSTRACT

An effective crop insurance system is crucial in cushioning income losses for farmers, financing inputs for agricultural production, and increasing access to agricultural credit to boost agricultural productivity. Annual average farmers registered under NAIS (2000-01 to 2015-16) were 169.53 lakhs, while under PMFBY (2016-172019-20) that were quite higher that is 425.16 lakhs. The annual area insured under NAIS was 244.82 lakh hectares while under PMFBY, it was 491.48 lakh hectares. The annual sum insured under NAIS was ₹ 29219.05 crores, while this is in PMFBY was ₹ 193006.30 crores annually. The annual average farmers benefitted under NAIS and PMFBY were 53.16 lakhs (29.88\% of total registered farmers) and 147.33 lakhs (32.67\% of total registered farmers). The claims premium ratio was found as 4.26 under NAIS and 4.59 under PMFBY. It suggested by spending one rupee under PMFBY, farmers have received the claims or 4.59 rupees. The sum insured to farmers premium ratio was 38.70 under NAIS and 51.57 under PMFBY suggests there is higher sum insured under PMFBY with given rupees. It is visible that the performance of PMFBY is higher over NAIS in terms of farmers insured, area covered, claims reported and paid. By creating the awareness and timely payment of claims, the coverage of PMFBY can be improved further.

Keywords: Crop Insurance, NAIS, PMFBY, Annual Performance, Features

The insurance in the agricultural production and society in general is indirect economic protection of life and property from the adverse effects of natural forces and accidents. Insurance promotes agricultural production by making the entrepreneurial activities of farmers more stable and more certain. Insurance reduces the uncertainty of farmers and the need to create individual savings accounts or funds, given that the need for cash reserves is reduced (Raulston et al., 2010). In most countries, private crop insurance is not sustainable without state subsidies (Skees et al., 1999), although their amount is constantly increasing. Having in mind global importance of food production, crop insurance is widely subsidized by governments of both developed and emerging countries.

In India crop insurance has a great role to play in managing risks in Indian agriculture sector. Though management of risk in agriculture is one of the priorities for government of India and policy makers, unfortunately, the progress of agricultural insurance in the country over the year is not up to the

How to cite this article: Kumar, V. (2020). Performance Analysis of National Agricultural Insurance Scheme (NAIS) and Pradhan Mantri Fasal Bima Yojna (PMFBY). Agro Economist - An International Journal, 7(2): 145-152.

Source of Support: None; Conflict of Interest: None 
mark to protect the Indian farmers, especially small and marginal farmers. According to the National Agriculture Policy 2000, "Despite technological and economic advancements, the condition of farmers continues to be unstable due to natural calamities and price fluctuations". In some extreme cases, these unfavorable events become one of the factors leading to farmer's suicides which are now assuming serious proportions (Raju and Chand, 2007). In developing countries, crop insurance is one of the many tools governments use to smooth farm incomes, in addition to policy mechanisms such as quotas, minimum support prices, input subsidies, and low interest agricultural loans, among others (Stutley, 2010).

To cover the risk which may occur in future, there is need to some provision and crop insurance is only mechanism available to safeguard against production risk in agriculture. For fulfilling this need, Government of India has introducing various schemes of crop insurance. Since the year 1999-2000, National Agricultural Insurance Scheme has been launched by National Agricultural Insurance Scheme Corporation of India and from Kharif2016, NAIS was taken over by new scheme as Pradhan Mantri Fasal Bima Yojna ( PMFBY). This research paper has made attempt to study the growth of National Agricultural Insurance Scheme and Pradhan Mantri Fasal Bima Yojna ( PMFBY).

\section{MATERIALS AND METHODS}

The performance analysis is mostly depended on secondary data collected from PMFBY website, and other literature. For NAIS, the data were collected from Rabi 1999-2000 - 2015-16 and for PMFBY, the data were collected from Kharif 2016 to 2019-20. The annual performance was analyzed and financial ratios were calculated to develop the comparison effective.

\section{RESULTS AND DISCUSSION}

\section{National Agriculture Insurance Scheme}

Government of India in co-ordination with General Insurance Corporation of India (GIC) had introduced scheme called the National Agricultural Insurance Scheme (NAIS) or Rashtriya Krishi Bima Yojana which commenced from Rabi season 1999-2000 and from April 2003, Agricultural Insurance Company of India Ltd. (AICIL) took over the implementation of the NAIS.

\section{Salient Features of the NAIS}

- Crops covered: all food grains, oilseeds, \& annual horticultural/commercial crops as sugarcane, potato, cotton, ginger, onion, turmeric, chilies, coriander, cumin, jute, tapioca, banana, \& pineapple etc.

- Scheme is available to both borrower and nonborrower farmers.

- The scheme is operated on area approach for widespread calamities and individual approach for localized calamities such as hailstorm, landslide, cyclone, flood etc.

- Small and marginal farmers entitled to subsidy of 50 percent of premium charged to be shared equally between central Government and State Government. The subsidy on premium has gradually been phased out and left with 10 per cent subsidy to small and marginal farmers.

- Optional scheme: Because at initial stage this scheme is on compulsory basis for non-loaner farmers now it made optional for both nonloaner and loaner farmers.

- Area approach: The scheme operates on "Area Approach" i.e. if the observed seasonal area yield per hectare of the insured crop for the defined insurance unit falls below a specific threshold yield, all insured farmers growing that crop in the defined area will receive the same claim payment. The defined area may be a Gram Panchayat, Mandal, Hobli, Circle, Phirka, Block Taluka etc.

The premium rates applicable on the sum insured are presented in Table 1.

\section{Important features and working procedure of PMFBY scheme}

The important features and working features of schemes are given below.

\section{Coverage of Farmers/Crops}

The Scheme covers all "Food \& Oilseeds crops" 
and "Annual Commercial/Horticultural Crops" for which past yield data is available. All farmers including sharecroppers and tenant farmers growing the notified crops in the notified areas are eligible for coverage (Table 2).

\section{Risks Covered/ Exclusions}

\section{Prevented Sowing/Planting/Germination Risk covered}

Insured area is prevented from sowing/ planting/ germination due to deficit rainfall or adverse seasonal/weather conditions.

\section{Standing Crop (Sowing to Harvesting)}

Comprehensive risk insurance is provided to cover yield losses due to non-preventable risks, viz. Drought, Dry spell, Flood, Inundation, widespread Pests and Disease attack, Landslides, Fire due to natural causes, Lightening, Storm, Hailstorm and Cyclone.

\section{Post-Harvest Losses}

Coverage is available only up to a maximum period of two weeks from harvesting, for those crops which are required to be dried in cut and spread / small bundled condition in the field after harvesting against specific perils of Hailstorm, Cyclone, Cyclonic rains and Unseasonal rains.

\section{Localized Calamities}

Loss/damage to notified insured crops resulting from occurrence of identified localized risks of Hailstorm, Landslide, Inundation, Cloud burst and Natural fire due to lightening affecting isolated farms in the notified area.

\section{Add-on coverage for crop loss due to attack by wild animals}

The States may consider providing add-on coverage for crop loss due to attack by wild animals wherever the risk is perceived to be substantial and is identifiable.

\section{Increased Farmer Awareness}

To increase the farmer coverage under this PMFBY scheme, efforts are made to create farmer awareness by using various marketing techniques so that maximum number of farmers can enroll and avail benefits of the scheme.

Table 1: The premium rates for different crops in NAIS

\begin{tabular}{lll}
\hline Season & Crops & Premium Rates \\
\hline Kharif & Bajara \& Oilseeds & $3.5 \%$ of sum insured or actuarial rate whichever is less. \\
& Other Kharif crops & $2.5 \%$ of sum insured or actuarial rate whichever is less. \\
Rabi & Wheat & $1.5 \%$ of sum insured or actuarial rate whichever is less. \\
& Other Rabi crops & $2 \%$ of sum insured or actuarial rate whichever is less. \\
Kharif + Rabi & Annual Commercial/Horticultural crops & Actuarial rate \\
\hline
\end{tabular}

Table 2: Crops covered and premium rates

\begin{tabular}{lll}
\hline Season & Crops & Maximum Premium payable by farmer \\
\hline Kharif & $\begin{array}{l}\text { All food grain and Oilseeds crops (all Cereals, } \\
\text { Millets, Pulses and Oilseeds crops) }\end{array}$ & $2.0 \%$ of SI or Actuarial rate, whichever is less \\
Rabi & $\begin{array}{l}\text { All food grain and Oilseeds crops (all Cereals, } \\
\text { Millets, Pulses and oilseeds) }\end{array}$ & 1.5\% of SI or Actuarial rate, whichever is less \\
Kharif and Rabi & $\begin{array}{l}\text { Annual Commercial/ Annual Horticultural } \\
\text { crops } \\
\text { Perennial horticultural crops (pilot basis) }\end{array}$ & $5 \%$ of SI or Actuarial rate, whichever is less \\
& $5 \%$ of SI or Actuarial rate, whichever is less \\
\hline
\end{tabular}




\section{Claims Process}

The PMFBY scheme operates on an area based approach process and the lowest level of notified area is called the Insurance Unit ( IU). If 'Actual Yield' per hectare of insured crop for the insurance unit (calculated on basis of requisite number of CCEs) in insured season, falls short of specified 'Threshold Yield' (TY), all insured farmers growing that crop in the defined area are deemed to have suffered shortfall of similar magnitude in yield. PMFBY seeks to provide coverage against such contingency.

\section{Area approach}

The scheme also operates on "Area Approach" i.e. if the observed seasonal area yield per hectare of the insured crop for the defined insurance unit falls below a specific threshold yield, all insured farmers growing that crop in the defined area will receive the same claim payment.

\section{Comparison between the two schemes}

The important points for comparison between the two schemes are presented in Table 3. Both the schemes covered all regions, crops and all types of farmers. The area approach was used in both schemes. The premium rates were made simple in PMFBY as one common premium rate for one season and $5 \%$ for horticultural crops. While in NAIS, for horticultural crops, acturial rates were applied, making it more difficult for convincing. In PMFBY, insurance cover was also provided for post harvest losses (Table 3).

Number of Farmers registered, area and sum insured and premium shared under NAIS

The total farmers registered under NAIS since its inception from 2000-01 to 2015-16 were 2712.55 lakhs, total area insured 3917.18 lakh hectares, total sum insured ₹ 467504.76 crores, total premium shared by farmers ₹ 11999.28 crores and total premium collected $₹ 14116.92$ crores (Table 4).

\section{Claims reported and claims paid, number of benefitted farmers and financial ratios under NAIS}

The total claims paid under NAIS were ₹ 56007.68 crores, total benefitted farmers 850.52 lakhs, percentage of farmers recieved claims 31.35 percent, claims to farmers premuim is found as 4.26 and sum insured to farmers premium was found as 38.70 (Table 5).

\section{Number of Farmers registered, area and sum insured and premium shared under PMFBY}

The total farmers registered under PMFBY since its inception from 2016-17 to 2019-20 were 1700.62 lakhs, total area insured 1965.91 lakh hectares, total Sum insured ₹ 772025.21 crores, total premium shared by farmers $₹ 14689.45$ crores and total premium collected ₹ 89638.60 crores (Table 6).

Table 3: Points of comparison between NAIS and PMFBY on the basis of features

\begin{tabular}{|c|c|c|}
\hline Points for comparison & NAIS & PMFBY \\
\hline Crops covered, including horticultural crops & All & All \\
\hline $\begin{array}{l}\text { Farmers covered including tenants, } \\
\text { sharecroppers }\end{array}$ & All & All \\
\hline Area and individual approach & Both & Both \\
\hline Kharif premium (percent of sum insured) & $\begin{array}{l}\text { For Bajra and oilseeds: } 3.5 \% \text { or actuarial rate, } \\
\text { which ever is less, For other crops: } 2.5 \%\end{array}$ & 2 Percent for all crops \\
\hline Rabi Premium & $\begin{array}{l}1.5 \% \text { for wheat and } 2 \% \text { for other or actuarial } \\
\text { rate whichever is less. }\end{array}$ & $1.5 \%$ for all rabi crops \\
\hline Horticultural crops & Actuarial rate & $5 \%$ \\
\hline Premium subsidy & $\begin{array}{l}10 \% \text { of premium for small and marginal } \\
\text { farmers }\end{array}$ & - \\
\hline Risk covered & All weather risks & All weather risks \\
\hline Post-harvest losses covered & No & Yes \\
\hline
\end{tabular}


Performance Analysis of National Agricultural Insurance Scheme (NAIS) and Pradhan Mantri...

Table 4: Number of farmers, area insured, sum insured and premium shared under NAIS

\begin{tabular}{llllllll}
\hline Years & $\begin{array}{l}\text { Number } \\
\text { of Farmers } \\
\text { covered } \\
\text { (in Lakhs) }\end{array}$ & $\begin{array}{l}\text { Area } \\
\text { Insured (In } \\
\text { Lakh ha) }\end{array}$ & $\begin{array}{l}\text { Sum Insured } \\
\text { (₹ Crores) }\end{array}$ & $\begin{array}{l}\text { Farmers' } \\
\text { Premium } \\
\text { (₹ Crores) }\end{array}$ & $\begin{array}{l}\text { State Govt. } \\
\text { Premium } \\
\text { (Share) } \\
\text { (₹ Crores) }\end{array}$ & $\begin{array}{l}\text { GoI Premium Gross } \\
\text { (Share) } \\
\text { (₹ Crores) }\end{array}$ & $\begin{array}{l}\text { Premium } \\
\text { (₹ Crores) }\end{array}$ \\
\hline $2000-01$ & 110.81 & 171.12 & 8862.48 & 182.66 & 28.65 & 28.65 & 239.95 \\
$2001-02$ & 106.52 & 160.34 & 8999.97 & 236.37 & 27.70 & 27.70 & 291.77 \\
$2002-03$ & 120.96 & 195.70 & 11269.24 & 312.38 & 25.80 & 25.80 & 363.97 \\
$2003-04$ & 123.92 & 188.24 & 11163.62 & 316.70 & 15.34 & 15.34 & 347.39 \\
$2004-05$ & 162.18 & 296.17 & 16944.82 & 510.58 & 12.11 & 12.11 & 534.80 \\
$2005-06$ & 167.22 & 277.49 & 18590.76 & 529.11 & 12.83 & 12.83 & 554.77 \\
$2006-07$ & 179.12 & 273.05 & 21301.58 & 572.24 & 23.62 & 14.31 & 610.17 \\
$2007-08$ & 184.43 & 281.42 & 24474.61 & 638.38 & 27.75 & 16.91 & 683.03 \\
$2008-09$ & 192.03 & 264.94 & 26814.78 & 701.54 & 84.89 & 21.23 & 807.66 \\
$2009-10$ & 239.34 & 336.70 & 38624.21 & 1022.47 & 101.14 & 30.95 & 1154.55 \\
$2010-11$ & 176.50 & 240.48 & 34721.45 & 880.36 & 110.18 & 29.42 & 1019.95 \\
$2011-12$ & 167.94 & 233.86 & 34771.04 & 856.51 & 90.17 & 25.34 & 972.03 \\
$2012-13$ & 167.91 & 243.85 & 42909.15 & 1041.65 & 254.46 & 30.24 & 1326.35 \\
$2013-14$ & 137.20 & 207.08 & 41554.15 & 1025.21 & 220.37 & 29.61 & 1275.19 \\
$2014-15$ & 167.38 & 207.70 & 45880.82 & 1154.31 & 204.85 & 38.94 & 1398.10 \\
$2015-16$ & 309.08 & 339.05 & 80622.09 & 2018.81 & 376.79 & 141.64 & 2537.24 \\
\hline Total & 2712.55 & 3917.18 & 467504.76 & 11999.28 & 1616.64 & 501.00 & 14116.92 \\
\hline Annual average & 169.53 & 244.82 & 29219.05 & 749.96 & 101.04 & 31.31 & 882.31 \\
\hline
\end{tabular}

Source: Department of Agriculture, Cooperation \& Farmers Welfare, MoA \& FW, GoI and Agricultural Statistics at a glance 2019, GoI.

Table 5: Claims, Number of farmers benefitted and financial ratio under NAIS

\begin{tabular}{|c|c|c|c|c|c|c|c|c|}
\hline Years & $\begin{array}{l}\text { Claims } \\
\text { Reported } \\
\text { (₹ Crores) }\end{array}$ & $\begin{array}{l}\text { Claims } \\
\text { Paid } \\
\text { (₹ Crores) }\end{array}$ & $\begin{array}{l}\text { Number } \\
\text { of Farmers } \\
\text { Benefitted } \\
\text { (Lakhs) }\end{array}$ & $\begin{array}{l}\text { Percentage } \\
\text { of farmers } \\
\text { received } \\
\text { claims }\end{array}$ & $\begin{array}{l}\text { Claims paid } \\
\text { to farmers } \\
\text { premium } \\
\text { ratio }\end{array}$ & $\begin{array}{l}\text { Claims paid } \\
\text { to gross } \\
\text { premium } \\
\text { ratio }\end{array}$ & $\begin{array}{l}\text { Sum insured } \\
\text { to farmers } \\
\text { premium } \\
\text { ratio }\end{array}$ & $\begin{array}{l}\text { Sum insured } \\
\text { to Gross } \\
\text { Premium } \\
\text { ratio }\end{array}$ \\
\hline $2000-01$ & 1289.66 & 1289.66 & 42.17 & 38.06 & 7.06 & 5.37 & 48.52 & 36.94 \\
\hline 2001-02 & 558.29 & 558.29 & 21.95 & 20.61 & 2.36 & 1.91 & 38.08 & 30.85 \\
\hline 2002-03 & 2012.94 & 2012.94 & 52.24 & 43.19 & 6.44 & 5.53 & 36.08 & 30.96 \\
\hline 2003-04 & 1149.79 & 1149.79 & 38.10 & 30.75 & 3.63 & 3.31 & 35.25 & 32.14 \\
\hline 2004-05 & 1198.92 & 1198.92 & 34.48 & 21.26 & 2.35 & 2.24 & 33.19 & 31.68 \\
\hline 2005-06 & 1424.75 & 1424.75 & 36.68 & 21.94 & 2.69 & 2.57 & 35.14 & 33.51 \\
\hline 2006-07 & 2292.19 & 2292.19 & 45.23 & 25.25 & 4.01 & 3.76 & 37.22 & 34.91 \\
\hline 2007-08 & 1725.54 & 1725.54 & 31.71 & 17.19 & 2.70 & 2.53 & 38.34 & 35.83 \\
\hline 2008-09 & 3887.62 & 3887.62 & 61.99 & 32.28 & 5.54 & 4.81 & 38.22 & 33.20 \\
\hline 2009-10 & 5118.11 & 5118.11 & 90.12 & 37.65 & 5.01 & 4.43 & 37.78 & 33.45 \\
\hline 2010-11 & 2299.71 & 2299.71 & 33.92 & 19.22 & 2.61 & 2.25 & 39.44 & 34.04 \\
\hline 2011-12 & 2208.99 & 2208.17 & 31.32 & 18.65 & 2.58 & 2.27 & 40.60 & 35.77 \\
\hline 2012-13 & 4896.88 & 4886.86 & 44.68 & 26.61 & 4.69 & 3.68 & 41.19 & 32.35 \\
\hline 2013-14 & 4323.62 & 4322.60 & 38.09 & 27.76 & 4.22 & 3.39 & 40.53 & 32.59 \\
\hline 2014-15 & 4288.02 & 4281.83 & 64.12 & 38.31 & 3.71 & 3.06 & 39.75 & 32.82 \\
\hline 2015-16 & 17557.79 & 17350.70 & 183.74 & 59.45 & 8.59 & 6.84 & 39.94 & 31.78 \\
\hline Total & 56232.82 & 56007.68 & 850.52 & 31.35 & & & & \\
\hline $\begin{array}{l}\text { Annual } \\
\text { average }\end{array}$ & 3514.55 & 3500.48 & 53.16 & 29.88 & 4.26 & 3.62 & 38.70 & 33.30 \\
\hline
\end{tabular}

Source: Department of Agriculture, Cooperation \& Farmers Welfare, MoA \& FW, GoI and Agricultural Statistics at a glance 2019, GoI. 
Table 6: Number of farmers, area insured, sum insured and premium shared under PMFBY

\begin{tabular}{llllllll}
\hline Year & $\begin{array}{l}\text { Total } \\
\text { farmers } \\
\text { insured, } \\
\text { in lakhs }\end{array}$ & $\begin{array}{l}\text { Total Sum } \\
\text { Insured } \\
\text { ₹ Crore }\end{array}$ & $\begin{array}{l}\text { Area } \\
\text { insured, } \\
\text { lakh } \\
\text { Hectares }\end{array}$ & $\begin{array}{l}\text { Total Farmers } \\
\text { Share in } \\
\text { Premium, } \\
\text { ₹ Crore }\end{array}$ & $\begin{array}{l}\text { State govt } \\
\text { share in } \\
\text { premium, } \\
\text { ₹ Crore }\end{array}$ & $\begin{array}{l}\text { Central govt } \\
\text { share in } \\
\text { premium, } \\
\text { ₹ Crore }\end{array}$ & $\begin{array}{l}\text { Total premium } \\
\text { ₹ Crore }\end{array}$ \\
\hline $2016-17$ & 562.72 & 194538.74 & 553.66 & 3812.34 & 8309.44 & 8121.36 & 20243.15 \\
$2017-18$ & 507.74 & 191786.48 & 494.65 & 3935.96 & 9560.05 & 9490.38 & 22986.39 \\
$2018-19$ & 349.33 & 201771.38 & 475.26 & 3670.61 & 9651.17 & 9283.71 & 22605.49 \\
$2019-20$ & 280.83 & 183928.61 & 442.34 & 3270.54 & 10587.39 & 9945.65 & 23803.57 \\
\hline Total & 1700.62 & 772025.21 & 1965.91 & 14689.45 & 38108.05 & 36841.10 & 89638.60 \\
\hline Annual average & 425.16 & 193006.30 & 491.48 & 3672.36 & 9527.01 & 9210.28 & 22409.65 \\
\hline
\end{tabular}

Source: Department of Agriculture, Cooperation \& Farmers Welfare, MoA \& FW, GoI and Agricultural Statistics at a glance 2019, GoI.

Table 7: Claims, Number of farmers benefitted and financial ratio under PMFBY

\begin{tabular}{lllllllll}
\hline & $\begin{array}{l}\text { Total } \\
\text { claims } \\
\text { Year } \\
\text { ₹ Crores }\end{array}$ & $\begin{array}{l}\text { Total } \\
\text { claims } \\
\text { paid, ₹ } \\
\text { Crores }\end{array}$ & $\begin{array}{l}\text { Total no } \\
\text { of farmers } \\
\text { benefitted, } \\
\text { lakhs }\end{array}$ & $\begin{array}{l}\text { Benefitted } \\
\text { farmers } \\
\text { of total } \\
\text { registered } \\
\text { farmers }(\%)\end{array}$ & $\begin{array}{l}\text { Claims } \\
\text { paid to } \\
\text { farmers } \\
\text { premium } \\
\text { ratio }\end{array}$ & $\begin{array}{l}\text { Claims } \\
\text { paid to } \\
\text { gross } \\
\text { premium } \\
\text { ratio }\end{array}$ & $\begin{array}{l}\text { Sum } \\
\text { insured } \\
\text { to } \\
\text { farmers } \\
\text { premium } \\
\text { ratio }\end{array}$ & $\begin{array}{l}\text { Sum insured } \\
\text { to Gross } \\
\text { Premium } \\
\text { ratio }\end{array}$ \\
\hline $2016-17$ & 15115.98 & 15109.77 & 131.80 & 23.42 & 3.96 & 0.75 & 51.03 & 9.61 \\
$2017-18$ & 20050.94 & 19943.71 & 159.04 & 31.32 & 5.07 & 0.87 & 48.73 & 8.34 \\
$2018-19$ & 19919.44 & 17359.21 & 151.14 & 43.27 & 4.73 & 0.77 & 54.97 & 8.93 \\
\hline Total & 55086.36 & 52412.69 & 441.98 & $*$ & $*$ & $*$ & $*$ & $*$ \\
\hline $\begin{array}{l}\text { Annual } \\
\text { average }\end{array}$ & 18362.12 & 17470.9 & 147.3267 & 32.67 & 4.59 & 0.79 & 51.57 & 8.96 \\
\hline
\end{tabular}

Source: Department of Agriculture, Cooperation \& Farmers Welfare, MoA \& FW, GoI and Agricultural Statistics at a glance 2019, GoI; * Figures for the years are being finalized.

\section{Claims reported and claims paid, number of} benefitted farmers and financial ratios under PMFBY

From 2016-17 to 2019-20, the total claims paid under PMFBY were ₹ 52412.69 crores, total benefitted farmers 441.14 lakhs (who received claims), percentage of farmers received claims 32.67 percent, claims to farmers premium is found as 4.59 and sum insured to farmers premium was found as 51.57 (Table 7).

\section{Comparison of Annual performance of NAIS and PMFBY}

The average annual performance of NAIS and PMFBY schemes is presented in table 8. Annual average farmers registered under NAIS (2000-01 to 2015-16) were 169.53 lakhs, while under PMFBY (2016-17- 2019-20) were quite higher that is 425.16 lakhs (Fig. 1).

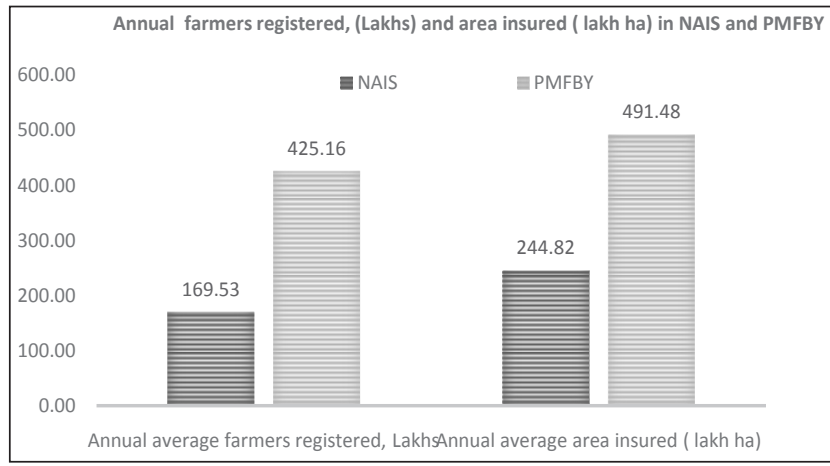

Fig. 1: Annual Farmers registered and Area insured under NAIS and PMFBY 
The annual area insured under NAIS was 244.82 lakh hectares while under PMFBY 491.48 lakh hectares. The annual sum insured under NAIS was ₹ 29219.05 crores, while this in PMFBY was ₹ 193006.30 crores annually. The annual premium shared by farmers under NAIS was ₹ 749.96 crores while this for PMFBY was ₹ 3672.36 crores annually. The annual claims reported and claims paid under NAIS were ₹ 3514.55 crores and $₹ 3500.48$ crores respectively. While under PMFBY (2016-17 to 2018-19), annual claims reported and claims paid were quite high, that is ₹ 18362.12 crores and ₹ 17470.90 crores respectively (Fig. 2).

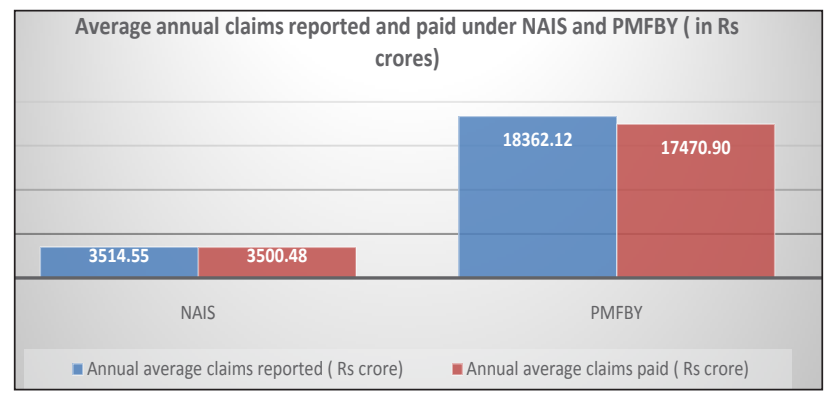

Fig. 2: Annual claims reported and Claims paid under NAIS and PMFBY

The annual average farmers benefitted under NAIS and PMFBY were 53.16 lakhs and 147.33 lakhs. The annual average percent of farmers who received claims (or benefitted) were $29.88 \%$ under NAIS and $32.67 \%$ under PMFBY (Fig. 3).

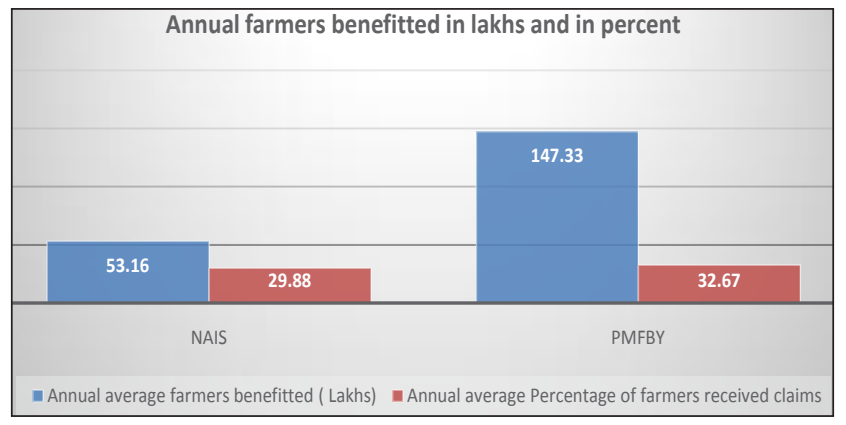

Fig. 3: Annual farmers benefitted under NAIS and PMFBY

The claim to premium ratio was found as 4.26 under NAIS and 4.59 under PMFBY. It suggested by spending one rupee under PMFBY, farmers have received the claims or 4.59 rupees. The claims paid to gross premium ratio was found as 3.62 under NAIS and 0.79 under PMFBY. The sum insured to farmers premium ratio was 38.70 under NAIS and 51.57 under PMFBY suggests there is higher sum insured under PMFBY with given rupees. The sum insured to gross premium ratio under NAIS was 33.30 and under PMFBY 8.96. It suggested that government shared higher part of premium under PMFBY scheme than in NAIS (Fig. 4).

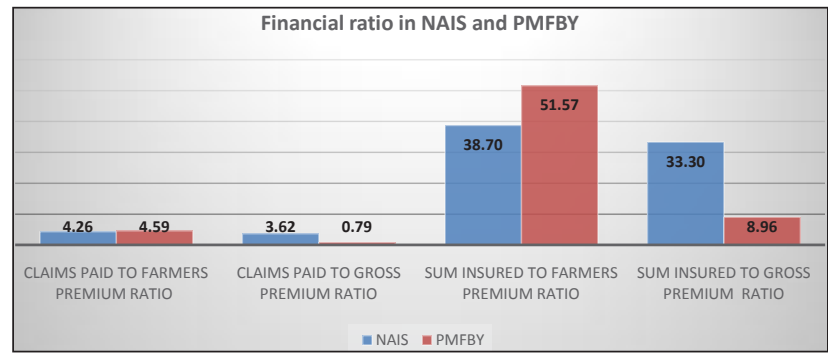

Fig. 4: Comparison of different financial ratios under NAIS and PMFBY

Table 8: Annual comparison of NAIS and PMFBY

\begin{tabular}{|c|c|c|}
\hline Particulars & NAIS & PMFBY \\
\hline $\begin{array}{l}\text { Annual average farmers } \\
\text { registered, Lakhs }\end{array}$ & 169.53 & $425.16^{*}$ \\
\hline $\begin{array}{l}\text { Annual average area insured } \\
\text { (lakh ha) }\end{array}$ & 244.82 & $491.48^{*}$ \\
\hline $\begin{array}{l}\text { Annual average Sum Insured } \\
\text { (₹ crores) }\end{array}$ & 29219.05 & 193006.30* \\
\hline $\begin{array}{l}\text { Annual average premium paid } \\
\text { by Farmers (₹ Crore) }\end{array}$ & 749.96 & $3672.36^{*}$ \\
\hline $\begin{array}{l}\text { Annual average State Govt. } \\
\text { Premium Share (in ₹ crore) }\end{array}$ & 101.04 & $9527.01^{*}$ \\
\hline $\begin{array}{l}\text { Annual average Central govt } \\
\text { Premium share (₹s Crore) }\end{array}$ & 31.31 & $9210.28^{*}$ \\
\hline $\begin{array}{l}\text { Annual average gross premium } \\
\text { collected ( } ₹ \text { crore) }\end{array}$ & 882.31 & $22409.65^{*}$ \\
\hline $\begin{array}{l}\text { Annual average claims reported } \\
(₹ \text { crore) }\end{array}$ & 3514.55 & 18362.12\# \\
\hline $\begin{array}{l}\text { Annual average claims paid } \\
(₹ \text { crore) }\end{array}$ & 3500.48 & 17470.90\# \\
\hline $\begin{array}{l}\text { Annual average farmers } \\
\text { benefitted (Lakhs) }\end{array}$ & 53.16 & 147.33\# \\
\hline $\begin{array}{l}\text { Annual average Percentage of } \\
\text { farmers received claims }\end{array}$ & 29.88 & $32.67 \#$ \\
\hline $\begin{array}{l}\text { Claims paid to farmers } \\
\text { premium ratio }\end{array}$ & 4.26 & $4.59 \#$ \\
\hline $\begin{array}{l}\text { Claims paid to gross premium } \\
\text { ratio }\end{array}$ & 3.62 & 0.79\# \\
\hline $\begin{array}{l}\text { Sum insured to farmers } \\
\text { premium ratio }\end{array}$ & 38.70 & $51.57 \#$ \\
\hline $\begin{array}{l}\text { Sum insured to Gross Premium } \\
\text { ratio }\end{array}$ & 33.30 & 8.96\# \\
\hline
\end{tabular}




\section{CONCLUSION}

An effective crop insurance system is crucial in cushioning income losses for farmers, financing inputs for agricultural production, and increasing access to agricultural credit to boost agricultural productivity. Both the scheme of National Agricultural Insurance scheme (NAIS) and Pradhan Mantri Fasal Bima Yojna (PMFBY) have successfully increased the awareness of farmers for insurance. Both the schemes have increased the coverage of insured area and added the number of farmers insured. But, it is visible the performance of PMFBY is higher over NAIS in terms of farmers insured, area covered, claims reported and paid. The PMFBY takes care of systemic or covariate risks associated with widespread vagaries of weather as well as idiosyncratic losses. No scheme previously has offered such a comprehensive protection (Ghosh 2019). By creating the awareness and timely payment of claims, the coverage of PMFBY can be improved further. The litmus test of any crop insurance program is quick assessment of crop damages and payment of claims into farmers' accounts directly, (Gulati et al. 2018).

\section{REFERENCES}

Ghosh, K.R. 2019. Performance evaluation of Pradhan Mantri Fasal Bima Yojana (PMFBY). “Uptake and WillingnessTo-Pay". Center for Management in Agriculture (CMA) Indian Institute of Management Ahmedabad (IIMA). Final Report.

Gulati, A., Terway, P. and Siraj, H. 2018. Crop Insurance in India: Key Issues and Way Forward. Indian Council for Research on International Economic Relations. Working paper 352; pp. 1-51.

Mahul, O. and Stutley, C.J. 2010. Government Support to Agricultural Insurance Challenges and Options for Developing Countries, the World Bank. Washington DC.

Raju, S.S. and Chand, R. 2007. Progress and Problems in Agricultural Insurance in India, Economic and Political Weekly, pp. 1905-1908.

Raulston, J.M., Richardson, J.W., Outlaw, J.L. and Knapek, G.M. 2010. Does Crop Insurance Reduce the Need for Cash Reserves in Savings Accounts?. Paper presented at the SAEA Annual Meeting, Orlando, FL.

Skees, J., Hazell, P. and Miranda, M. 1999. New Approaches to Crop Yield Insurance in Developing Countries. EPTD Discussion Paper 55. International Food Policy Research Institute, Washington, DC. 